\title{
Potassium Depletion Downregulates Chloride-absorbing Transporters in Rat Kidney
}

\author{
Hassane Amlal, ${ }^{*}$ Zhaohui Wang, ${ }^{\star}$ and Manoocher Soleimani ${ }^{* \ddagger}$ \\ *Department of Medicine, University of Cincinnati School of Medicine, Cincinnati, Ohio 45267-0585; and ${ }^{\ddagger}$ Veterans Affairs Medical \\ Center at Cincinnati, Cincinnati, Ohio 45267
}

\begin{abstract}
Potassium depletion (KD) causes renal chloride wasting, suggesting defect(s) in $\mathrm{Cl}^{-}$reabsorption in renal tubules. To determine whether alterations in expression of the major $\mathrm{Cl}^{-}$transporter genes might contribute to the chloride wasting, we analyzed their expression in renal cortex and medulla of animals placed on KD diet. Feeding KD diet to rats resulted in significant hypokalemia at $14 \mathrm{~d}$ but not at $6 \mathrm{~d}$. Northern hybridization revealed that mRNA levels for the apical Na-K-2Cl cotransporter in the medulla decreased by 56 and $51 \%$ at 6 and $14 \mathrm{~d}$ of KD diet, respectively. Functional studies in tubular suspensions from medullary thick ascending limb demonstrated that the Na-K-2Cl cotransporter activity decreased by $\sim 45$ and $\sim 37 \%$ at 6 and $14 \mathrm{~d}$ of KD diet, respectively. mRNA levels for the thiazide-sensitive $\mathrm{Na}-\mathrm{Cl}$ cotransporter decreased by 57 and $64 \%$ at 6 and $14 \mathrm{~d}$ of KD diet. Decreased expression of the apical $\mathrm{Na}-\mathrm{Cl}$ and the $\mathrm{Na}-\mathrm{K}-2 \mathrm{Cl}$ cotransporters became evident at 48 and $72 \mathrm{~h}$ of $\mathrm{KD}$, respectively. Urinary chloride excretion increased at $48 \mathrm{~h}$ and further increased at $72 \mathrm{~h}$ of KD, correlating with suppression of the $\mathrm{Na}-\mathrm{Cl}$ and the $\mathrm{Na}-\mathrm{K}-2 \mathrm{Cl}$ transporters.

Our results indicate that increased urinary chloride loss in KD results from suppression of the chloride-absorbing transporters. Downregulation of chloride transporters in $\mathrm{KD}$ is an early event and can lead to hypochloremia and subsequently hypovolemia and decreased glomerular filtration rate. (J. Clin. Invest. 1998. 101:1045-1054.) Key words: potassium depletion $\bullet$ kidney $\bullet$ chloride excretion $\bullet \mathrm{Na}-\mathrm{K}-2 \mathrm{Cl}$ cotransport $\bullet \mathrm{Na}-\mathrm{Cl}$ cotransport
\end{abstract}

\section{Introduction}

Potassium depletion (KD) ${ }^{1}$ increases urinary chloride excretion in mammalians $(1,2)$. Increased chloride loss can lead to volume depletion and, subsequently, to decreased glomerular filtration rate (GFR) $(3,4)$. Hypochloremia, resulting from en-

Address correspondence to Manoocher Soleimani, University of Cincinnati Medical School, 231 Bethesda Ave., MSB 5502, Cincinnati, OH 45267-0585. Phone: 513-558-5463; FAX: 513-558-4309; E-mail: soleimm@ucbeh.san.uc.edu

Received for publication 20 May 1997 and accepted in revised form 29 December 1997.

1. Abbreviations used in this paper: $\mathrm{C}$, control; $\mathrm{KD}$, potassium depletion; mTAL, medullary thick ascending limb.

The Journal of Clinical Investigation

Volume 101, Number 5, March 1998, 1045-1054

http://www.jci.org hanced chloride loss, has been shown to contribute to the maintenance of metabolic alkalosis in hypokalemia $(2,5)$. Segmental analysis of the rat nephron by micropuncture technique indicates that KD causes increased chloride loss by several nephron segments, including medullary thick ascending limb of Henle (mTAL) and distal tubule (6).

Chloride wasting occurring as a result of potassium depletion would necessarily involve a reduction in chloride reabsorption in one or more nephron segments (6). However, little is known about the mechanisms underlying this deficit. Chloride reabsorption across the apical membranes of mTAL and distal tubule is mediated primarily by two distinct transporters that have been recently cloned and characterized (7-9). Most of the $\mathrm{Cl}^{-}$reabsorption in the ascending limb of Henle occurs via the apical $\mathrm{Na}-\mathrm{K}-2 \mathrm{Cl}$ cotransporter $(10-12)$, whereas the majority of chloride reabsorption in the distal tubule is mediated via the thiazide-sensitive $\mathrm{Na}-\mathrm{Cl}$ cotransporter $(13,14)$. In addition to the above mentioned chloride-absorbing transporters, a basolateral $\mathrm{Na}-\mathrm{K}-2 \mathrm{Cl}$ cotransporter is expressed in various nephron segments and could potentially affect urinary chloride excretion (15).

To gain insight into the molecular mechanism of increased renal chloride loss in potassium depletion, the expression of renal chloride transporters was studied in rats on KD diet. Further, the time course of generation of hypokalemia was correlated with the expression of the chloride transporters. The results demonstrated that KD downregulated the apical $\mathrm{Na}-\mathrm{Cl}$ and the $\mathrm{Na}-\mathrm{K}-2 \mathrm{Cl}$ cotransporters and consequently increased the urinary chloride excretion. The results further indicated that suppression of chloride-absorbing transporters precedes the onset of hypokalemia and likely correlates with intracellular potassium depletion. Suppression of the apical Na-K-2Cl and $\mathrm{Na}-\mathrm{Cl}$ cotransporters may be the molecular basis of increased renal chloride wasting observed in potassium depletion.

\section{Methods}

Animal model. Potassium depletion was induced by placing male Sprague Dawley rats (175-200 g) on a KD diet (16) for up to $14 \mathrm{~d}$. The KD diet was prepared by replacing $\mathrm{K}^{+}$salt with $\mathrm{Na}^{+}$. The ingredients in the diet for both groups (per each two pounds) consisted of casein $340 \mathrm{~g}$, corn starch $200 \mathrm{~g}$, sucrose $320 \mathrm{~g}$, corn oil $35 \mathrm{ml}$, vitamins (ICN Pharmaceuticals, Inc., Cleveland, OH) $10 \mathrm{~g}, \mathrm{CaHPO}_{4}$ $1.0 \mathrm{~g}, \mathrm{MgSO}_{4} 0.6 \mathrm{~g}, \mathrm{Na}_{2} \mathrm{HPO}_{4} 0.68 \mathrm{~g}$, and $\mathrm{NaCl} 0.6 \mathrm{~g}$. For control diet, $\mathrm{K}_{2} \mathrm{HPO}_{4} 0.83 \mathrm{~g}$ and $\mathrm{KCl} 0.95 \mathrm{~g}$ were added. For $\mathrm{KD}$ diet, $\mathrm{K}_{2} \mathrm{HPO}_{4}$ and $\mathrm{KCl}$ were replaced with $\mathrm{Na}_{2} \mathrm{HPO}_{4}$ and $\mathrm{NaCl}$, respectively. Rats were housed two per cage and had unlimited access to food and water. Body weights were recorded at the beginning and at the end of experiments. Animals were killed by intraperitoneal injection of $50 \mathrm{mg}$ of sodium pentobarbitol at days 1-6 and at day 14 of the experiment. Plasma $\mathrm{K}^{+}$was measured by flame photometry. Kidneys were removed, trimmed of fat, hilus, and capsule, weighed, snap frozen in liquid nitrogen, and stored at $-70^{\circ} \mathrm{C}$ until used.

Urinary chloride excretion. Animals were housed in metabolic 
cages and placed on regular $(n=4)$ or $\mathrm{KD}(n=6)$ diet. $24 \mathrm{~h}$ urine samples were collected for six consecutive days, and urinary chloride excretion was measured by ion-specific electrode assay. In parallel series of experiments animals were placed on $\mathrm{KD}$ or regular diet and killed at time intervals correlating with the urine collection experiments (days 1-6, $n=3$ for each group). Kidneys were removed and RNA was isolated from cortex, outer medulla, and inner medullas.

RNA isolation. Total cellular RNA was extracted from kidney (whole kidney, cortex, medulla, or outer medulla) by the method of Chomczynski and Sacchi (17). In brief, 0.5-1 g of tissue was homogenized at room temperature in $10 \mathrm{ml}$ Tri Reagent (Molecular Research Center Inc., Cincinnati, Ohio). RNA was extracted by phenol/chloroform and precipitated by isopropanol (17). RNA was quantitated by spectrophotometry and stored at $-80^{\circ} \mathrm{C}$.

Northern hybridization. Total RNA samples (30 $\mu \mathrm{g}$ per lane) were fractionated on a $1.2 \%$ agarose-formaldehyde gel and transferred to Magna NT nylon membranes (MSI) using $10 \times$ SSPE as transfer buffer. Membranes were cross-linked by UV light and baked for $1 \mathrm{~h}$. Hybridization was performed according to Church and Gilbert (18). Briefly, membranes were preprehybridized for $1 \mathrm{~h}$ in $0.1 \times$ $\mathrm{SSPE} / 1 \%$ SDS solution at $65^{\circ} \mathrm{C}$. The membranes were then prehybridized for $1-3 \mathrm{~h}$ at $65^{\circ} \mathrm{C}$ with $0.5 \mathrm{M}$ sodium phosphate buffer, $\mathrm{pH}$ $7.2,7 \%$ SDS, $1 \%$ BSA, $1 \mathrm{mM}$ EDTA, and $100 \mu \mathrm{g} / \mathrm{ml}$ sonicated carrier DNA. Thereafter, the membranes were hybridized overnight in the above solution with $30-50 \times 10^{6} \mathrm{cpm}$ of ${ }^{32} \mathrm{P}$-labeled DNA probe for apical Na-K-2Cl, Na-Cl, basolateral Na-K-2Cl or $\mathrm{K}^{+}-\mathrm{Cl}^{-}$cotransporter. The cDNA probes were labeled with ${ }^{32} \mathrm{P}$-deoxynucleotides using the RadPrime DNA labeling kit (GIBCO BRL, Gaithersburg, $\mathrm{MD})$. The membranes were washed twice in $40 \mathrm{mM}$ sodium phosphate buffer, $\mathrm{pH} 7.2,5 \%$ SDS, $0.5 \%$ BSA, and $1 \mathrm{mM}$ EDTA for 10 min at $65^{\circ} \mathrm{C}$, washed four times in $40 \mathrm{mM}$ sodium phosphate buffer, $\mathrm{pH} 7.2,1 \% \mathrm{SDS}$, and $1 \mathrm{mM}$ EDTA for $10 \mathrm{~min}$ at $65^{\circ} \mathrm{C}$, exposed to PhosphorImager cassette at room temperature for 24-72 h, and read by PhosphorImager (Molecular Dynamics, Sunnyvale, CA). Densitometric scanning of the blots was performed by PhosphorImager. The following rat PCR product fragments were used as specific probes in the Northern blot analyses: apical $\mathrm{Na}-\mathrm{K}-2 \mathrm{Cl}$ cotransporter, nucleotides 509-3,237; Na-Cl cotransporter, nucleotides 1,436-2,800; and basolateral Na-K-2Cl cotransporter, nucleotides $906-1,238$ and 312,300; and $\mathrm{K}^{+}-\mathrm{Cl}^{-}$cotransporter, nucleotides $280-2,363$. These probes have $<60 \%$ homology with each other and under high stringency hybridization conditions do not cross react with one another. This was confirmed by lack of cross hybridization of the cDNA probe for the $\mathrm{Na}-\mathrm{Cl}$ cotransporter (which is exclusively expressed in the cortex) to the mTAL Na-K-2Cl cotransporter, and by the distinct pattern of abundance and regulation of the apical $\mathrm{Na}-\mathrm{K}-2 \mathrm{Cl}$ cotransporter versus the basolateral cotransporter in medulla of $\mathrm{KD}$ animals (see $\mathrm{Re}$ sults).

mTAL tubular suspension preparation. mTAL tubular suspension was isolated as previously described (19-21). In brief, 8 or 10 kidneys of four or five anesthetized male Sprague Dawley rats (200-300 g in body weight) were bathed in situ for 1-2 min with ice-cold solution to avoid anoxic damage to medullary tissues and improve cell viability. The kidneys were then cut into thin slices along the corticopapillary axis into ice-cold Hanks' solution containing $(\mathrm{mM}): 137 \mathrm{NaCl}, 5.4$ $\mathrm{KCl}, 25 \mathrm{NaHCO}_{3}, 0.3 \mathrm{Na}_{2} \mathrm{HPO}_{4}, 0.4 \mathrm{KH}_{2} \mathrm{PO}_{4}, 0.5 \mathrm{MgCl}_{2}, 10$ Hepes, 5 glucose, 5 leucine, $1 \mathrm{mg} / \mathrm{ml}$ bovine serum albumin (BSA) and bubbled with $95 \% \mathrm{O}_{2}-5 \% \mathrm{CO}_{2}, \mathrm{pH} 7.38$. Small tissue pieces of inner stripes of outer medulla were then subjected at $37^{\circ} \mathrm{C}$ to successive 6 -min periods of collagenase digestion $(0.40 \mathrm{~g} /$ liter $)$. The mTAL tubules were then harvested by sieving the supernatants through a 75 $\mu \mathrm{m}$ opening nylon mesh to separate mTAL fragments from isolated cells and small fragments of other medullary tissues. The mTAL tubular suspensions were resuspended in an appropriate volume of the desired medium. The final suspension contained almost exclusively mTAL tubules of 75-200 $\mu \mathrm{m}$ of length (>95\%), occasional thin descending limb fragments and no isolated cells or medullary collecting tubules (19-21). mTAL fragments were suspended at $37^{\circ} \mathrm{C}$ in a $\mathrm{CO}_{2^{-}}$
Table I. Composition of Experimental Solutions

\begin{tabular}{lccc}
\hline & \multicolumn{3}{c}{ Solutions } \\
\cline { 2 - 4 } \multicolumn{1}{c}{ Compound } & $\mathrm{A}$ & $\mathrm{B}$ & $\mathrm{C}$ \\
\hline $\mathrm{NaCl}$ & 135 & 125 & - \\
$\mathrm{KCl}$ & 3 & 3 & - \\
$\mathrm{K}_{2} \mathrm{HPO}_{4}$ & 0.8 & 0.8 & 0.8 \\
$\mathrm{CaCl}_{2}$ & 1 & 1 & - \\
$\mathrm{MgCl}_{2}$ & 1 & 1 & - \\
$\mathrm{Hepes}$ & 10 & 10 & 10 \\
$\mathrm{Glucose}_{\text {Leucine }}$ & 5 & 5 & 5 \\
BaCl & 5 & 5 & - \\
Ba-SCN & - & 10 & 10 \\
Na-gluconate & - & - & 135 \\
K-gluconate & - & - & 1 \\
Ca-gluconate & - & - & 1 \\
Mg-gluconate & - & - & \\
& - & &
\end{tabular}

Concentrations are in mM. All solutions were bubbled with $100 \% \mathrm{O}_{2}$, adjusted to $\mathrm{pH} 7.40$ with (Tris[hydroxymethyl]aminomethane).

free medium composed of $135 \mathrm{mM} \mathrm{NaCl}, 3 \mathrm{mM} \mathrm{KCl}, 0.8 \mathrm{mM}$ $\mathrm{K}_{2} \mathrm{HPO}_{4}, 1 \mathrm{mM} \mathrm{CaCl}_{2}, 1 \mathrm{mM} \mathrm{MgCl} 2,10 \mathrm{mM}$ Hepes, $5 \mathrm{mM}$ glucose, $5 \mathrm{mM}$ L-leucine (Solution $A$, Table I) that in addition contained $1 \mathrm{mg} / \mathrm{ml}$ BSA. The $\mathrm{pH}$ was adjusted at 7.4 using Tris, and the solution was bubbled with $100 \% \mathrm{O}_{2}$.

Intracellular $\mathrm{pH}$ measurements. $\mathrm{pH}_{\mathrm{i}}$ in mTAL suspensions was measured with the use of BCECF as previously described (19-21). In brief, aliquots of BCECF-loaded tubules were diluted into glass cuvettes containing $2 \mathrm{ml}$ of the experimental medium, and BCECF fluorescence was monitored with the use of a Delta Scan dual excitation spectrofluorometer (PTI, double-beam fluorometer; Photon Technology International, Brunswick, NJ) that was equipped with a waterjacketed, temperature-controlled cuvette holder and magnetic stirrer. Fluorescence intensity was recorded at emission wavelength $525 \mathrm{~nm}$ and two excitations wavelengths at 500 and $450 \mathrm{~nm}$, respectively. The fluorescence ratio values (F500/F450) were converted into $\mathrm{pH}_{\mathrm{i}}$ values with use of calibration curves that were established daily by Triton X-100 methods, as described previously (19-21).

Measurement of $\mathrm{Na}-\mathrm{K}-2 \mathrm{Cl}$ activity. The $\mathrm{Na}-\mathrm{K}-2 \mathrm{Cl}$ cotransport activity was assessed as previously described (21). Briefly, the Na-K$2 \mathrm{Cl}$ cotransporter activity was measured by determining the rate of intracellular acidification caused by entry into the cells of $\mathrm{NH}_{4}{ }^{+}$via this transport mechanism upon abrupt application of $4 \mathrm{mM} \mathrm{NH}_{4} \mathrm{Cl}$ $(19,20) . \mathrm{NH}_{4}{ }^{+}$entry into rat mTAL cells occurs via several transport pathways $(19,20)$. Amiloride $(1 \mu \mathrm{M})$ inhibits the mTAL $\mathrm{NH}_{4}{ }^{+}$conductance (19), whereas barium blocks both $\mathrm{K}^{+} / \mathrm{NH}_{4}{ }^{+}\left(\mathrm{H}^{+}\right)$antiport and $\mathrm{NH}_{4}^{+}\left(\mathrm{K}^{+}\right)-\mathrm{Cl}^{-}$cotransport $(19,20)$, and bumetanide (or furosemide) inhibits $\mathrm{Na}^{+}-\mathrm{K}^{+}\left(\mathrm{NH}_{4}^{+}\right)-2 \mathrm{Cl}^{-}$cotransport $(19,20)$. mTAL cells incubated in a $\mathrm{CO}_{2}$-free Hepes/Tris buffered medium (Solution $A$, Table I) had a $\mathrm{pH}_{\mathrm{i}}$ of 7.33-7.39. After $\mathrm{NH}_{4} \mathrm{Cl}$ addition, a very rapid initial cellular alkalinization occurred due to immediate $\mathrm{NH}_{3}$ entry which stopped when intracellular and extracellular $\left[\mathrm{NH}_{3}\right]$ became equal $\left(\mathrm{NH}_{3}\right.$ equilibrium). The initial alkalinization was then followed by a relatively rapid and profound drop in $\mathrm{pH}_{\mathrm{i}}$. The initial rate $\left(\mathrm{dpH}_{\mathrm{i}} / \mathrm{dt}\right)$ of this acidification, which is exclusively due to $\mathrm{NH}_{4}{ }^{+}$entry (19), was calculated according to established methods (19) and was found to be $2.75260 .06 \mathrm{pH} / \mathrm{min}$ in the absence of any inhibitor $(n=5$, see Fig. $4 A$, Control). In the presence of $1 \mu \mathrm{M}$ amiloride and $10 \mathrm{mM}$ barium (Solution $B$, Table I), a noticeable cell acidification was still present after $\mathrm{NH}_{4} \mathrm{Cl}$ addition which was due to $\mathrm{Na}^{+}-\mathrm{K}^{+}\left(\mathrm{NH}_{4}^{+}\right)-2 \mathrm{Cl}^{-}$activity, since it was completely abolished by bumetanide at $100 \mu \mathrm{M}$ (see Fig. 4 A). 
Similar results have been reported previously (19). It is worth mentioning that the $\mathrm{Na}^{+}-\mathrm{K}^{+}-\mathrm{ATPase}$ transports $\mathrm{NH}_{4}{ }^{+}$poorly under these experimental conditions $\left(4 \mathrm{mM} \mathrm{NH}_{4}{ }^{+}\right.$versus $\left.5 \mathrm{mM} \mathrm{K}^{+}\right)$since its affinity for $\mathrm{NH}_{4}{ }^{+}$is approximately five times lower than that for $\mathrm{K}^{+}$ (22). Therefore, the $\mathrm{Na}^{+}-\mathrm{K}^{+}\left(\mathrm{NH}_{4}^{+}\right)-2 \mathrm{Cl}^{-}$cotransporter activity was defined as the bumetanide-sensitive $4 \mathrm{mM} \mathrm{NH}_{4}{ }^{+}$-induced cell acidification $\left(\mathrm{dpH}_{\mathrm{i}} / \mathrm{dt}\right)$ observed in the presence of $1 \mu \mathrm{M}$ amiloride and 10 $\mathrm{mM}$ barium $(19,20)$.

Materials. ${ }^{32} \mathrm{P}-\mathrm{dCTP}$ was purchased from New England Nuclear (Boston, MA). Nitrocellulose filters and other chemicals were purchased from Sigma Chemical Co. (St. Louis, Mo). RadPrime DNA labeling kit was purchased from GIBCO BRL. BCECF was from Molecular Probes, Inc. (Eugene, OR).

Statistical analysis. The data are expressed as mean \pm SEM where appropriate. For statistical analysis of mRNA expression experiments, the PhosphorImager readings of three separate Northern hybridizations were obtained and analyzed. Statistical analysis was determined using one way ANOVA. $P<0.05$ was considered statistically significant.

\section{Results}

Rats fed a KD diet developed significant hypokalemia at $14 \mathrm{~d}$ but not at $6 \mathrm{~d}$ (23). We used the same kidney RNA for the present Northern hybridization experiments. For functional experiments, rats were placed on a KD or control (C) diet and killed 6 or $14 \mathrm{~d}$ later. While serum $\left[\mathrm{K}^{+}\right]$was not statistically different between the two groups at $6 \mathrm{~d}(4.4 \pm 0.3 \mathrm{mEq} / \mathrm{liter}$ in $\mathrm{KD}$ versus $4.9 \pm 0.4$ in $\mathrm{C}, n=4, P>0.05$ ), the values were lower in $\mathrm{KD}$ animals, indicating possible reduction in serum $\left[\mathrm{K}^{+}\right]$. Serum $\left[\mathrm{K}^{+}\right]$was significantly lower after 2 wk of $\mathrm{KD}$ diet $(2.9 \pm 0.3 \mathrm{mEq} / \mathrm{liter}$ in $\mathrm{KD}$ versus $5.3 \pm 0.4 \mathrm{mEq} / \mathrm{liter}$ in $\mathrm{C}, n=4$, $P<0.01)$. Serum $\left[\mathrm{HCO}_{3}^{-}\right]$in rats on $\mathrm{KD}$ diet for two weeks was not significantly different than control $\left(\mathrm{HCO}_{3}^{-}\right.$was $27 \pm 1.9$ in KD versus $25 \pm 1.7 \mathrm{mEq} /$ liter in $\mathrm{C}, n=4, P>0.05)$.

The effect of KD on mRNA expression levels of the various $\mathrm{Cl}^{-}$transporters was examined. Equal loading of RNA samples was confirmed by ethidium bromide staining of nitrocellulose membrane-transferred RNA of the various gels that were used for Northern hybridization (Fig. $1 A$ ). Fig. $1 A a$ is a membrane that was used for the apical $\mathrm{Na}-\mathrm{K}-2 \mathrm{Cl}$ cotransporter labeling, stripped and used for the $\mathrm{Na}-\mathrm{Cl}$ cotransporter Northern hybridization. Figure $1 A b$ is a membrane that was used for the basolateral $\mathrm{Na}-\mathrm{K}-2 \mathrm{Cl}$ cotransporter Northern hybridization. The four left lanes in both figures are from the whole kidney and the four right lanes are from the cortex and medulla of control and KD animals. Fig. $1 B, a$ and $b$ verifies equal loading of RNA samples of Fig. $1 A, a$ and $b$, respectively, by measuring mRNA levels for the constitutive control GAPDH.

Potassium depletion decreases urinary chloride reabsorp-
A

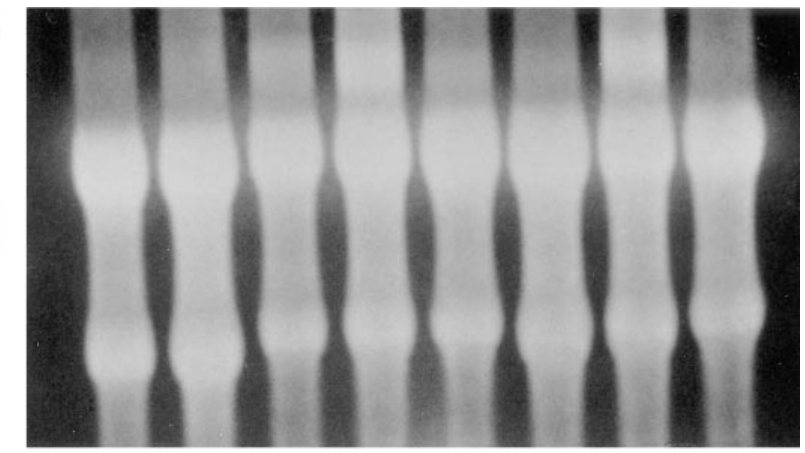

b

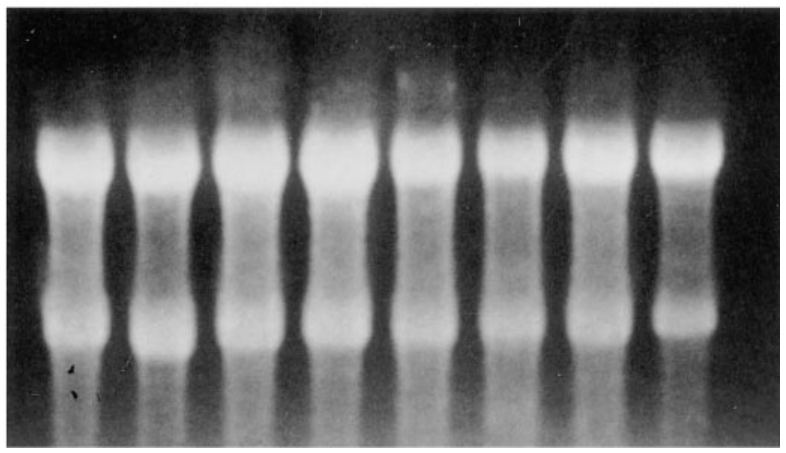

B
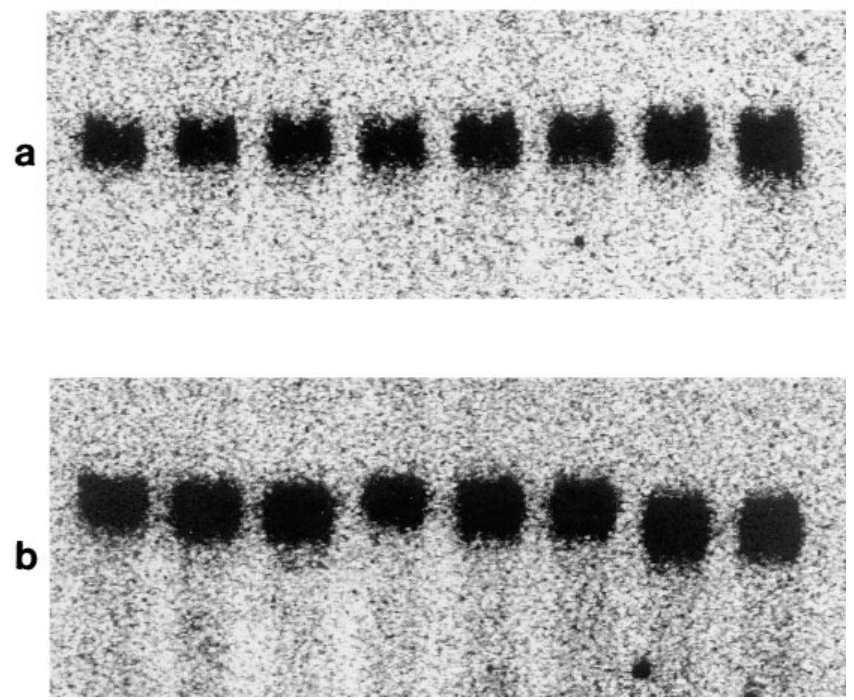

Figure 1. (A) Ethidium bromide staining of nitrocellulose membrane-transferred RNA. Representative membranes that were used for the Northern hybridization in Figs. 2, 3, and 6-9 are shown. Membrane $a$ was used for the apical Na-K-2Cl cotransporter labeling, stripped, and used for the Na-Cl cotransporter labeling. Membrane $b$ was used for the basolateral Na-K-2Cl cotransporter labeling. (B) Levels of mRNA expression of GAPDH (a constitutive control) were measured by Northern hybridization in membranes that were used in $A$. Membranes $a$ and $b$ correspond to $a$ and $b$ in $A$. Results in the following figures are expressed as the cotransporter mRNA levels/GAPDH. 


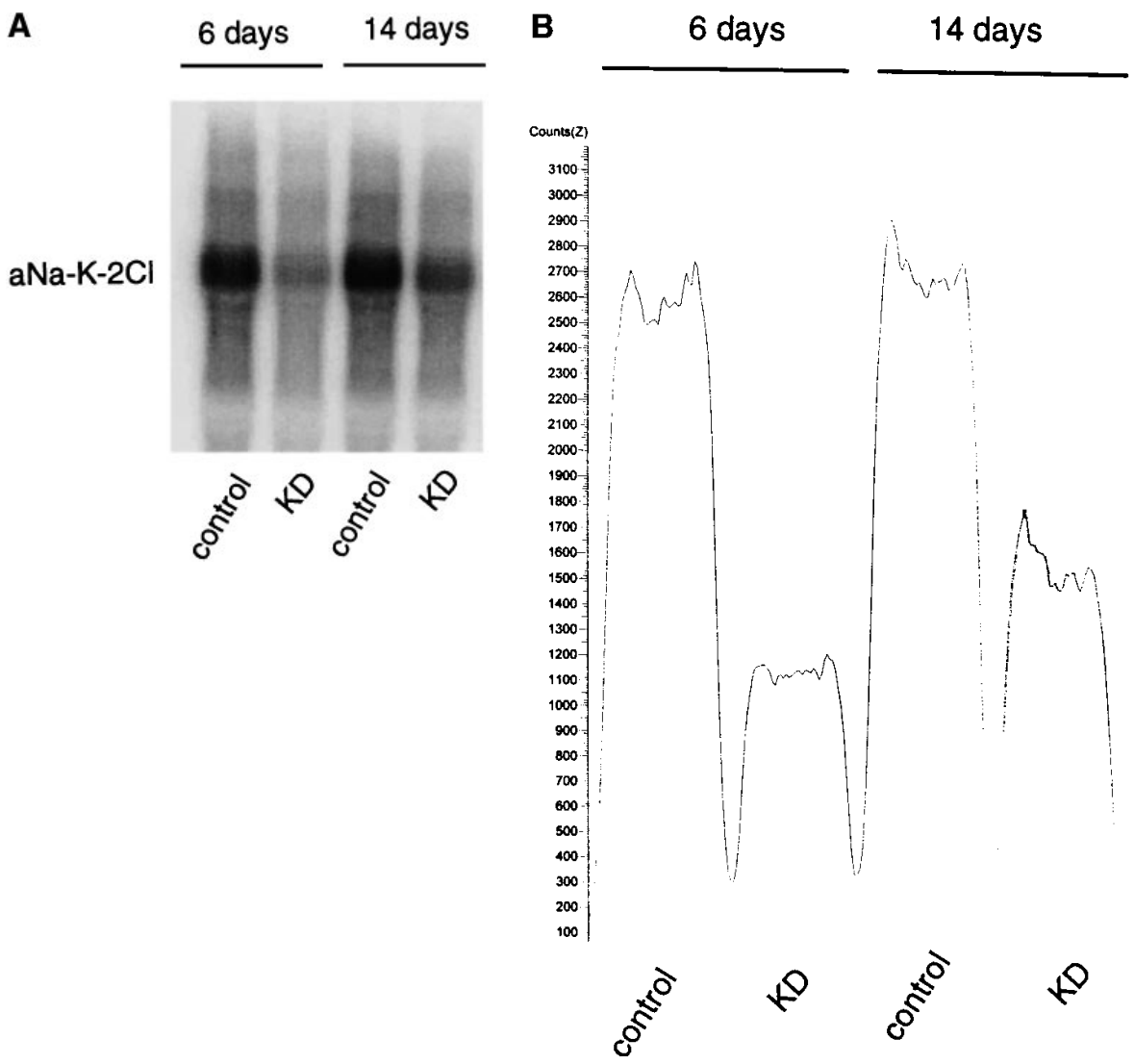

Figure 2. Apical Na-K-2Cl cotransporter Northern hybridization. $(A)$ Representative Northern hybridization showing apical $\mathrm{Na}-\mathrm{K}-2 \mathrm{Cl}$ cotransporter transcript levels at 6 and $14 \mathrm{~d}$ of KD, respectively. $(B)$ Densitometric scanning of the results shown in $A$. Corresponding nitrocellulose membranetransferred RNA and GAPDH expression are shown in Fig. 1. Densitometric scanning units are arbitrary. Apical Na-K-2Cl cotransporter transcript size was $4.6 \mathrm{~kb}$. tion in ascending limb of Henle $(2,6)$. We first examined the expression of the apical $\mathrm{Na}-\mathrm{K}-2 \mathrm{Cl}$ cotransporter mRNA in kidneys from rats on KD diet. Fig. $2 A$ shows that expression of the apical Na-K-2Cl cotransporter decreased at 6 and $14 \mathrm{~d}$ of KD diet. Densitometric scanning of the results, Fig. $2 \mathrm{~B}$, shows significant suppression of the apical Na-K-2Cl cotransporter, with mRNA levels decreasing by $56 \pm 4$ and $51 \pm 5 \%$ at 6 and $14 \mathrm{~d}$ of KD diet, respectively $(P<0.05$ for each time point, $n=3$ ).

Apical $\mathrm{Na}-\mathrm{K}-2 \mathrm{Cl}$ cotransporter expression in the kidney is limited to cortical and medullary thick ascending limb of Henle. The Northern hybridization studies in KD animals (Fig. 2) were obtained from whole kidney. In the next series of experiments total RNA was extracted from the renal cortex or medulla of control and KD animals ( $6 \mathrm{~d}$ or 2 wk on K-free diet) and used for Northern hybridization. The results in Fig. $3 \mathrm{~A}$ show that the apical Na-K-2Cl cotransporter is predominantly expressed in the medulla and its mRNA levels at $2 \mathrm{wk}$ are decreased by $63 \pm 6 \%$ in KD animals $(P<0.05$ versus control, $n=3$ ). Na-K-2Cl cotransporter was less abundant in the cortex and did not show any noticeable suppression in KD. Expression of the apical $\mathrm{Na}-\mathrm{K}-2 \mathrm{Cl}$ cotransporter in the medulla is limited to the mTAL $(7,8,12)$. To determine whether decreased mRNA expression of the cotransporter in the medulla (Fig. $3 A$ ) correlates with its expression in mTAL, RNA was isolated from mTAL tubule suspension of rats on KD diet for two weeks and examined by Northern hybridization. As shown in Fig. $3 B$, mRNA levels for the apical Na-K-2Cl cotransporter in mTAL were significantly decreased in animals on
KD diet for 2 wk (mRNA levels decreased by $55 \%$ in KD animals versus control, $P<0.05, n=3$ ).

To determine if $\mathrm{KD}$ affects the apical $\mathrm{Na}-\mathrm{K}-2 \mathrm{Cl}$ cotransporter activity, mTAL tubule suspensions were isolated and studied. To determine the apical $\mathrm{Na}-\mathrm{K}-2 \mathrm{Cl}$ cotransporter activity, we took advantage of the fact that $\mathrm{NH}_{4}^{+}$can be transported on this transporter by binding to its extracellular $\mathrm{K}^{+}$binding site (see Methods for details). mTAL tubule suspensions were exposed to $\mathrm{NH}_{4}^{+}$and the rate of cell acidification following the initial cell alkalinization was studied as an index of $\mathrm{NH}_{4}{ }^{+}$transport into the cells. The activity of the apical Na$\mathrm{K}-2 \mathrm{Cl}$ cotransporter was then assayed as the rate of bumetanide-sensitive $\mathrm{NH}_{4}{ }^{+}$entry in mTAL cells. To determine the bumetanide-sensitive $\mathrm{NH}_{4}{ }^{+}$transport, mTAL cells were incubated in a $\mathrm{CO}_{2}$-free Hepes/Tris-buffered medium (Solution $B$, Table I) that in addition contained $1 \mu \mathrm{M}$ amiloride and $10 \mathrm{mM}$ barium, inhibitors of other $\mathrm{NH}_{4}^{+}$-carrying transporters in mTAL (see Methods). As shown in Fig. $4 \mathrm{~B}$, the bumetanidesensitive $\mathrm{Na}-\mathrm{K}-2 \mathrm{Cl}$ cotransporter activity decreased in rats on KD diet for 2 wk by $37 \%$, with the rate of acidification of $-1.525 \pm 0.085$ and $-0.957 \pm 0.015 \mathrm{pH} / \mathrm{min}$ for control and KD rats, respectively ( $n=5$ for each group, $P<0.007$ ).

To verify that KD directly affects the bumetanide sensitive and $\mathrm{Cl}^{-}$-dependent $\mathrm{NH}_{4}{ }^{+}$transport pathway mediated via the $\mathrm{Na}^{+}-\mathrm{K}^{+}\left(\mathrm{NH}_{4}{ }^{+}\right)-2 \mathrm{Cl}^{-}$cotransporter, $\mathrm{NH}_{4}{ }^{+}$-induced cell acidification was studied in the presence or absence of $\mathrm{Cl}^{-}$in the experimental solution. Accordingly, mTAL tubule suspensions were incubated in a $\mathrm{Cl}$-free medium (chloride was replaced isoosmotically with gluconate; Solution $C$, Table I) and ex- 
Figure 3. (A) Apical Na-K-2Cl cotransporter Northern
A

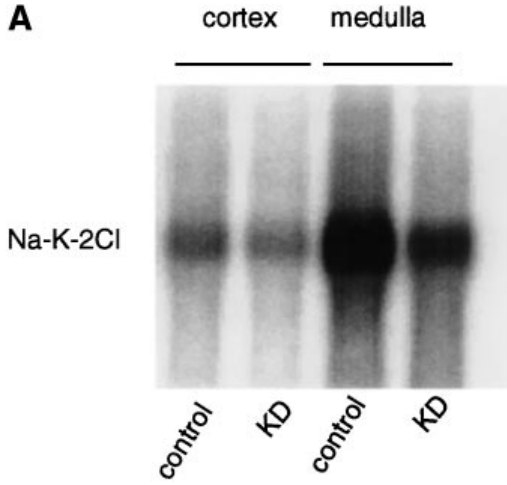

B

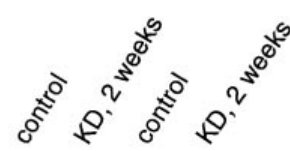

apical $\mathrm{Na}-\mathrm{K}-2 \mathrm{Cl}$

GADPH

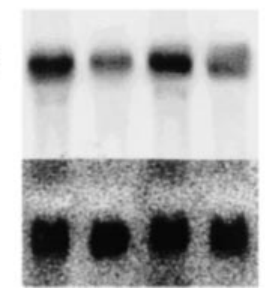

hybridization. A representative Northern hying the apical Na-K-2Cl cotransporter mRNA expression in cortex and medulla at $14 \mathrm{~d}$ of potassium depletion. Corresponding nitrocellulose membranetransferred RNA and GAPDH expression are shown in Fig. 1. Na-K-2Cl cotransporter transcript size was $\sim 4.6 \mathrm{~kb} .30 \mu \mathrm{g}$ RNA were loaded on each lane. $(B)$ Apical Na-K-2Cl cotransporter Northern hybridization in mTAL. Representative blots demonstrating the apical Na-K-2Cl cotransporter mRNA expression in mTAL of control and KD animals at $14 \mathrm{~d}$ of potassium depletion. bridization demonstrat-

posed to $4 \mathrm{mM} \mathrm{NH}_{4}$-SCN in the presence of inhibitors of other $\mathrm{NH}_{4}{ }^{+}$transport pathways ( $1 \mathrm{mM}$ amiloride, $\left.10 \mathrm{mM} \mathrm{Ba}-\mathrm{SCN}\right)$ and $100 \mathrm{mM}$ DPC (an inhibitor of $\mathrm{Cl}^{-}$channel) (Fig. 5). At steady state $\mathrm{pH}_{\mathrm{i}}$, abrupt addition of $100 \mathrm{mM} \mathrm{Cl}^{-}$profoundly acidified the cells $\left(\Delta \mathrm{pH}_{\mathrm{i}}=0.238 \pm 0.006 \mathrm{pH}\right.$ units in control group, $\mathrm{n}=4$, Fig. 5). This $\mathrm{Cl}^{-}$-dependent cell acidification was decreased significantly in mTAL tubule suspensions isolated from KD animals $\left(\Delta \mathrm{pH}_{\mathrm{i}}=0.142 \pm 0.006, n=5, P<0.0002\right.$ versus control). It should be mentioned that $\mathrm{Cl}^{-}$-induced cells acidification was observed only in the presence of $\mathrm{NH}_{4}{ }^{+}$, and was mediated exclusively via bumetanide-sensitive $\mathrm{Na}^{+}-$ $\mathrm{K}^{+}\left(\mathrm{NH}_{4}^{+}\right)-2 \mathrm{Cl}^{-}$cotransport when barium and amiloride were present.

The major mechanism for reabsorption of chloride in the distal tubule is via the thiazide-sensitive $\mathrm{Na}-\mathrm{Cl}$ cotransporter $(7,13,14)$. The effect of potassium depletion on the expression of the Na-Cl cotransporter was next studied. As shown in Fig. $6 \mathrm{~A}$, the $\mathrm{Na}-\mathrm{Cl}$ cotransporter expression decreased significantly both at 6 and $14 \mathrm{~d}$ of $\mathrm{K}^{+}$-free diet, with densitometric scanning (Fig. $6 \mathrm{~B}$ ) showing mRNA levels decreasing by $57 \pm 4 \%$ at $6 \mathrm{~d}(P<0.03, n=3)$ and by $64 \pm 5 \%$ at $14 \mathrm{~d}(P<$ $0.03, n=3)$. In the next series of experiments total RNA was extracted from the renal cortex or medulla of control and KD animals ( 2 wk on $\mathrm{K}$-free diet) and the $\mathrm{Na}-\mathrm{Cl}$ cotransporter mRNA was analyzed by Northern hybridization. The results, shown in Fig. 7, demonstrate that the apical Na-Cl cotransporter mRNA is expressed predominantly in the cortex and its levels are decreased by $60 \pm 5 \%$ in KD animals $(P<0.03$ versus control, $n=3$ ). The low expression of the $\mathrm{Na}-\mathrm{Cl}$ cotrans-
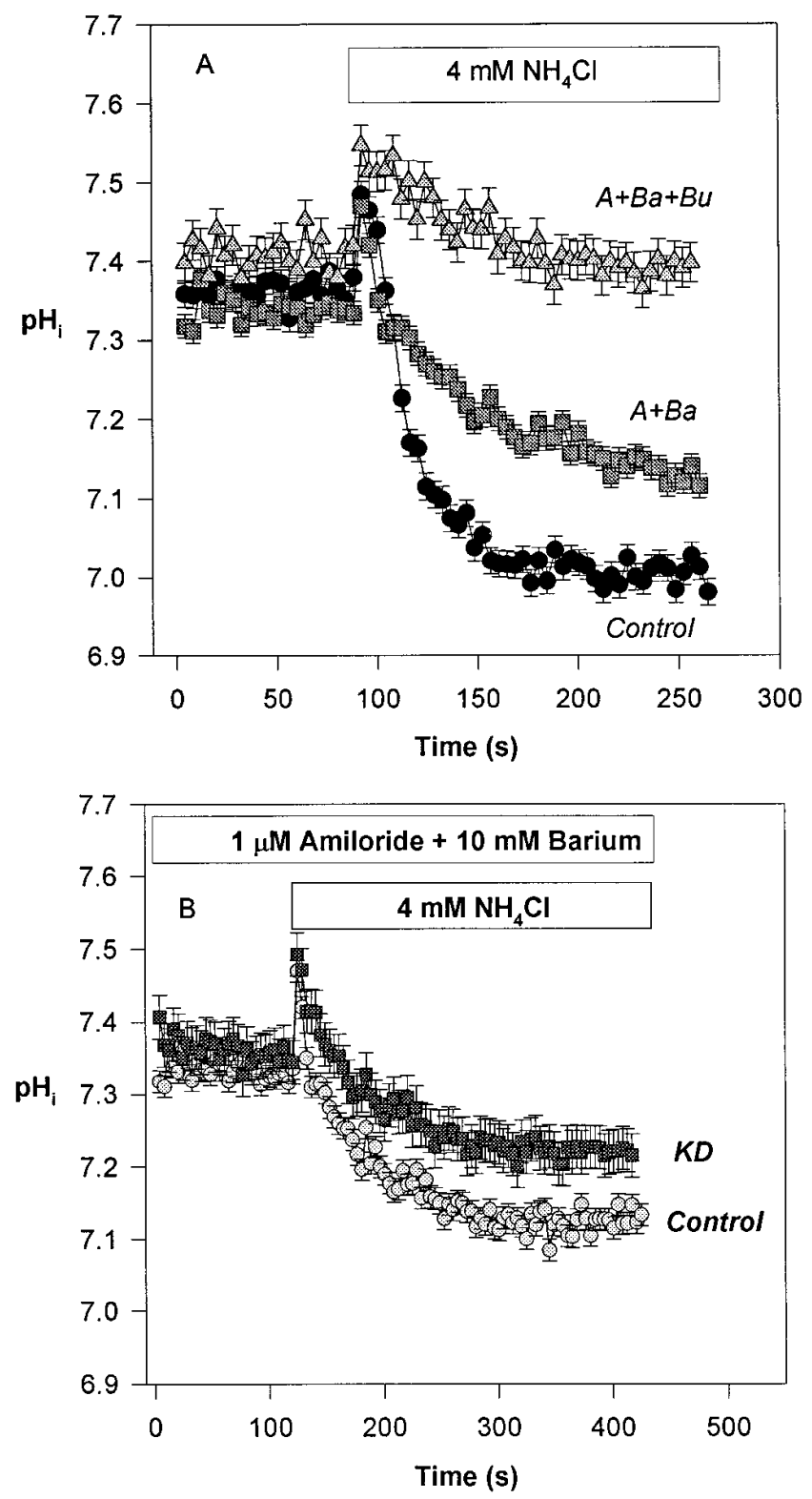

Figure 4. Effect of $\mathrm{KD}$ on $\mathrm{Na}-\mathrm{K}-2 \mathrm{Cl}$ cotransport activity as examined by the bumetanide-sensitive $\mathrm{NH}_{4}{ }^{+}$-induced cell acidification. $(A)$ mTAL tubule suspensions from normal rats were exposed to $4 \mathrm{mM}$ $\mathrm{NH}_{4} \mathrm{Cl}$ in the absence of any inhibitor (Control) or presence of $1 \mu \mathrm{M}$ amiloride and $10 \mathrm{mM} \mathrm{BaCl}_{2}(A+B a)$ or $1 \mu \mathrm{M}$ amiloride, $10 \mathrm{mM}$ $\mathrm{BaCl}_{2}$ and $100 \mu \mathrm{M}$ bumetanide $(A+B a+B u)$. (B) The bumetanidesensitive $\mathrm{NH}_{4}{ }^{+}$entry into mTAL cells (via $\mathrm{Na}^{+}-\mathrm{K}^{+}\left[\mathrm{NH}_{4}^{+}\right]-2 \mathrm{Cl}^{-}$ cotransport) is inhibited by $37 \%$ in cells from $\mathrm{KD}$ animals compared with control $(P<0.007)$. Each data point is mean \pm SEM of five experiments.

porter mRNA in the medulla is likely due to minor contamination by the cortical RNA (Fig. 7).

$\mathrm{KD}$ causes suppression of the apical $\mathrm{Na}-\mathrm{Cl}$ and $\mathrm{Na}-\mathrm{K}-2 \mathrm{Cl}$ cotransporters which can lead to renal chloride wasting. Increased urinary chloride excretion has been established after $6 \mathrm{~d}$ of $\mathrm{KD}(2)$, however, the onset of renal chloride wasting is not known. Rats were housed in metabolic cages and placed on regular or KD diet. Daily urine output was collected for six 


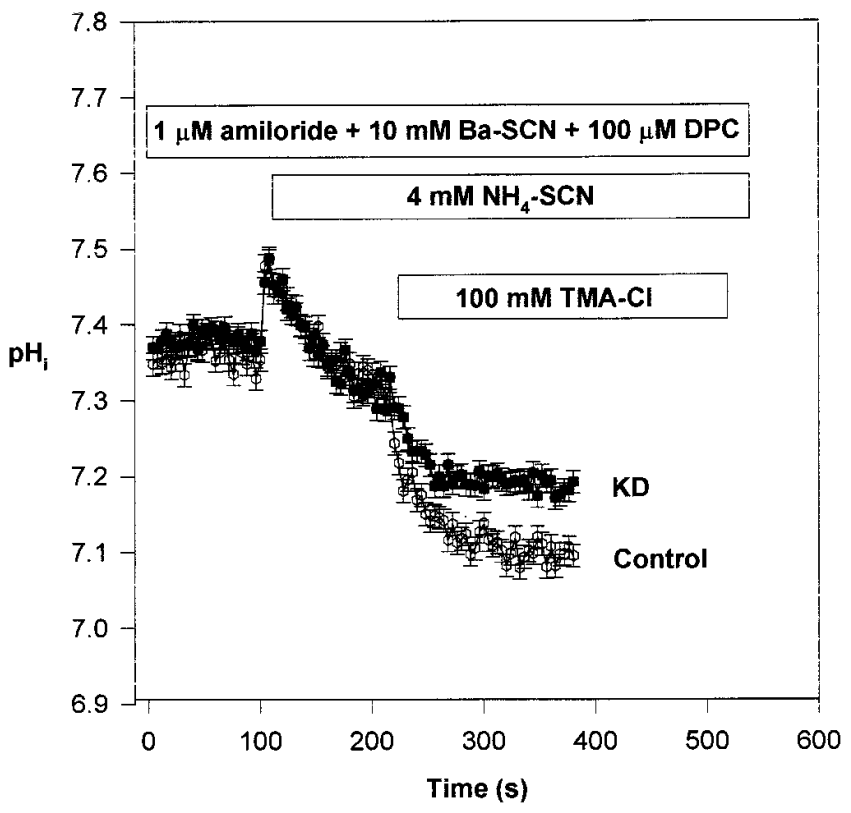

Figure 5. Effect of $\mathrm{KD}$ on $\mathrm{Na}-\mathrm{K}-2 \mathrm{Cl}$ cotransport activity as examined by bumetanide-sensitive, $\mathrm{Cl}^{-}$-dependent $\mathrm{NH}_{4}{ }^{+}$entry into mTAL cells. mTAL cells were incubated in $\mathrm{Cl}^{-}$-free medium in the presence of $4 \mathrm{mM} \mathrm{NH}_{4}$-SCN, $1 \mu \mathrm{M}$ amiloride, $10 \mathrm{mM} \mathrm{Ba-SCN}$, and $100 \mu \mathrm{M}$ DPC. At steady state, addition of $100 \mathrm{mM}$ TMA-Cl markedly acidified the cells. This acidification is greater in normal rats $\left(\Delta \mathrm{pH}_{\mathrm{i}}=\right.$ $0.238)$ versus $\mathrm{KD}$ rats $\left(\Delta \mathrm{pH}_{\mathrm{i}}=0.142\right), P<0.0002$. Each data point is mean \pm SEM of five experiments.

consecutive days, and urinary chloride excretion was measured by the ion-specific electrode assay. As demonstrated in Fig. 8, urinary chloride excretion was normal at $24 \mathrm{~h}$, increased at $48 \mathrm{~h}$, further increased at $72 \mathrm{~h}$ and remained elevated at $6 \mathrm{~d}$ of KD.

To investigate the molecular basis of increased urinary chloride excretion in $\mathrm{KD}$, expression of the apical $\mathrm{Na}-\mathrm{Cl}$ cotransporter in the cortex was examined. As shown in Fig. 9, apical $\mathrm{Na}-\mathrm{Cl}$ cotransport expression decreased at 48 of $\mathrm{KD}$ and was further suppressed at $72 \mathrm{~h}$ and $6 \mathrm{~d}$, with mRNA levels decreasing by 53,61 , and $72 \%$ at $48 \mathrm{~h}, 72 \mathrm{~h}$ and $6 \mathrm{~d}$, respectively $(P<0.02$ for each time point versus control). In separate series of experiments, the $\mathrm{Na}-\mathrm{Cl}$ cotransporter mRNA expression at $24 \mathrm{~h}$ of KD was examined and was found to be the same as control (data not shown).

Expression of the apical $\mathrm{Na}-\mathrm{K}-2 \mathrm{Cl}$ cotransporter in outer medulla ${ }^{3}$ was examined next. The apical Na-K-2Cl cotransporter expression was not affected at $48 \mathrm{~h}$ but was significantly

2. The animals ingested $\sim 15$ g per day of diet which gives a chloride ingestion of $\sim 420 \mu \mathrm{M}$ for K-deficient or control animals. The control animals excreted $\sim 200 \mu \mathrm{M}$ of chloride per $100 \mathrm{~g}$ body weight per $24 \mathrm{~h}$ (or $\sim 400 \mu \mathrm{M}$ per animal per day) which is equal to their intake. Potassium-deficient animals, however, excreted $\sim 350-400 \mu \mathrm{M}$ chloride per $100 \mathrm{~g}$ body weight per $24 \mathrm{~h}$ on days 3 to 6 (or $\sim 700-800 \mu \mathrm{M}$ per animal per day), indicating significant chloride wasting (compared with $420 \mu \mathrm{m}$ daily chloride intake).

3. RNA was extracted from outer medulla to enrich the abundance of the Na-K-2Cl cotransporter, as mTAL tubules are exclusively located in this kidney section.

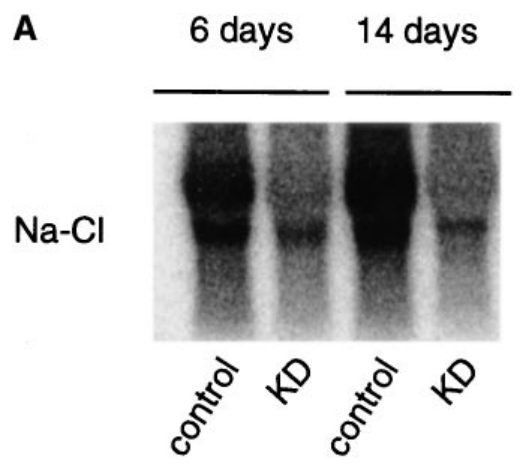

B

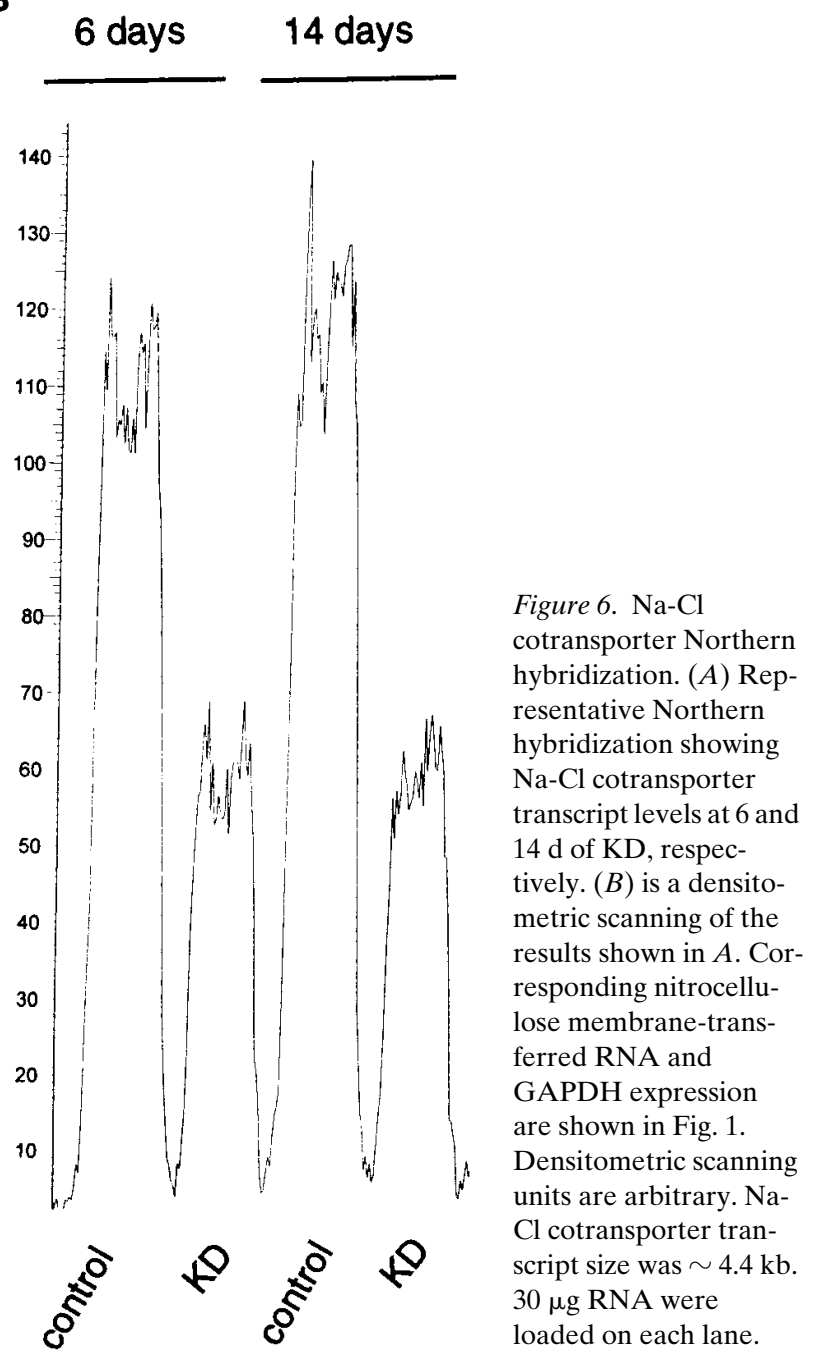

suppressed at $72 \mathrm{~h}$ and at $6 \mathrm{~d}$ of KD experiments (Fig. 10), with mRNA levels decreasing by 56 and $63 \%$ at $72 \mathrm{~h}$ and $6 \mathrm{~d}$, respectively ( $P<0.03$ for each time point versus control, $n=3$ ). To determine whether suppression of the apical $\mathrm{Na}-\mathrm{K}-2 \mathrm{Cl}$ cotransporter mRNA levels parallels alterations in its activity, mTAL tubule suspensions were prepared and utilized for functional studies in a manner similar to Fig. 4. The results demonstrated that the apical $\mathrm{Na}-\mathrm{K}-2 \mathrm{Cl}$ cotransporter activity was unchanged at $48 \mathrm{~h}$ but decreased at $72 \mathrm{~h}$ and remained suppressed at $6 \mathrm{~d}$ of KD (Fig. 11). Taken together, these stud- 
Figure 7. Na-Cl cotransporter Northern hybridization. Representative Northern hybridization showing Na$\mathrm{Cl}$ cotransporter mRNA expression in cortex and medulla at $14 \mathrm{~d}$ of potassium depletion. Corresponding nitrocellulose membranetransferred RNA and GAPDH expression are shown in Fig. 1. Na$\mathrm{Cl}$ cotransporter transcript size was $\sim 4.4 \mathrm{~kb}$. $30 \mu \mathrm{g}$ RNA were loaded on each lane.

ies strongly suggest that renal chloride wasting in KD results in large part from downregulation of these two cotransporters, with the $\mathrm{Na}-\mathrm{Cl}$ cotransporter responsible for increased renal chloride excretion after $48 \mathrm{~h}$ and the Na-K-2Cl cotransporter contributing after $72 \mathrm{~h}$ of KD.

In addition to the above chloride-absorbing transporters, a basolateral $\mathrm{Na}-\mathrm{K}-2 \mathrm{Cl}$ cotransporter is expressed in several nephron segments in the cortex and medulla (15). As shown in Fig. $12, A$ and $B$, the basolateral $\mathrm{Na}-\mathrm{K}-2 \mathrm{Cl}$ cotransporter mRNA levels remained the same both at 6 and $14 \mathrm{~d}$ of K1-free diet (mRNA levels in KD groups were $93 \pm 5 \%$ at $6 \mathrm{~d}$ and $98 \pm 6 \%$ at $14 \mathrm{~d}$ as compared with control, $P>0.05$ for both time points, $n=3$ for each group). The expression of the basolateral $\mathrm{Na}-\mathrm{K}-2 \mathrm{Cl}$ cotransporter remained unchanged in cortex and medulla (Fig. $12 \mathrm{C}$ ).

\section{Discussion}

These studies demonstrated that mRNA levels for the bumetanide-sensitive apical $\mathrm{Na}-\mathrm{K}-2 \mathrm{Cl}$ cotransporter decreased in

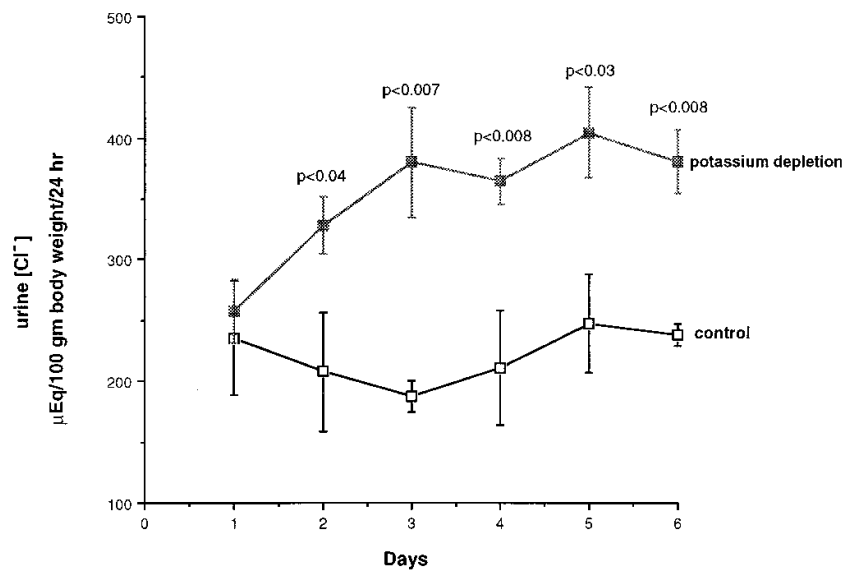

Figure 8. Urinary chloride excretion in potassium depletion. 24-h urine samples were collected for six consecutive days, and chloride concentrations were determined. $n=4$ for control and $n=6$ for KD animals. $P$ values are for comparison between potassium depletion and control animals.

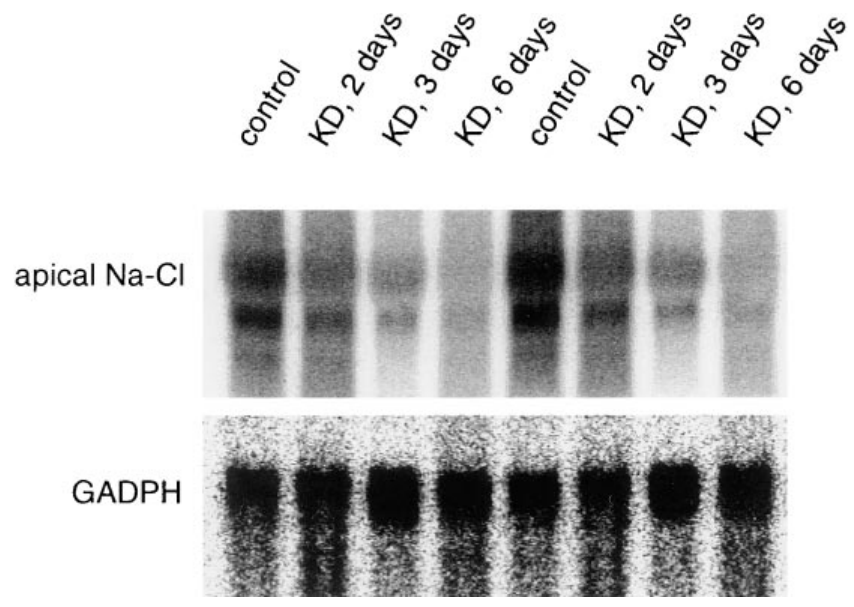

Figure 9. Apical $\mathrm{Na}-\mathrm{Cl}$ cotransporter Northern hybridization. mRNA expression of the apical $\mathrm{Na}-\mathrm{Cl}$ cotransporter was measured in the renal cortex of rats on KD diet for correlation with urinary chloride excretion studies in Fig. 8.

KD (Figs. 2 and 3). Studies indicated that mRNA suppression of this cotransporter was associated with decreased activity in KD (Figs. 4 and 5). Further, Northern hybridization experiments showed that mRNA levels for the $\mathrm{Na}-\mathrm{Cl}$ cotransporter decreased in KD (Figs. 6 and 7). Decreased expression of $\mathrm{Cl}^{-}$ cotransporters was unique to the luminal isoforms, as suggested by the lack of effect of KD on mRNA levels for the basolateral Na-K-2Cl cotransporter (Fig. 12). In addition, the studies indicated that KD resulted in increased urinary chloride excretion (Fig. 8), and this effect correlated with suppression of the apical chloride-absorbing transporters (Figs. 9-11).

Potassium depletion is associated with increased renal chloride excretion in rat (2) and man (1). Micropuncture studies in rat kidney have demonstrated that $\mathrm{KD}$ impairs $\mathrm{Cl}^{-}$reabsorption in the proximal tubule, mTAL, and distal tubule (6, 24). The majority of $\mathrm{Cl}^{-}$reabsorption in the mTAL is mediated by the apical $\mathrm{Na}-\mathrm{K}-2 \mathrm{Cl}$ cotransporter (10-12). This transporter has distinct binding sites for $\mathrm{K}^{+}, \mathrm{Na}^{+}$, and $\mathrm{Cl}^{-}$and is inhibited by bumetanide and furosemide $(11,25)$. The fact that $\mathrm{KD}$ causes impairment of $\mathrm{Cl}^{-}$reabsorption in mTAL suggests that the apical $\mathrm{Na}-\mathrm{K}-2 \mathrm{Cl}$ cotransporter is likely to be involved; however, no studies have examined this transporter in potassium depletion. The results of our studies demonstrate that functional activity of the $\mathrm{Na}-\mathrm{K}-2 \mathrm{Cl}$ cotransporter decreases in KD (Figs. 4, 5, and 11). Northern hybridization studies reveal that mRNA levels for the mTAL apical Na-K-2Cl cotransporter also decreased during KD (Figs. 2, 3, and 10), indicating regulation at the transcriptional level. ${ }^{4} \mathrm{~A}$ decrease in both expression and activity of the $\mathrm{Na}-\mathrm{K}-2 \mathrm{Cl}$ cotransporter in $\mathrm{KD}$ could cause decreased absorption of $\mathrm{Cl}^{-}$in mTAL and increased renal $\mathrm{Cl}^{-}$excretion. It is worth mentioning that

4. Changes in the protein abundance can affect the activity of the transporter independent of gene regulation. Moreover, a change in message might not reflect a parallel change in the amount of transport protein and, by inference, activity. To address these concerns with regard to the apical $\mathrm{Na}-\mathrm{K}-2 \mathrm{Cl}$ cotransporter, we have measured the expression and activity of the transporter. 

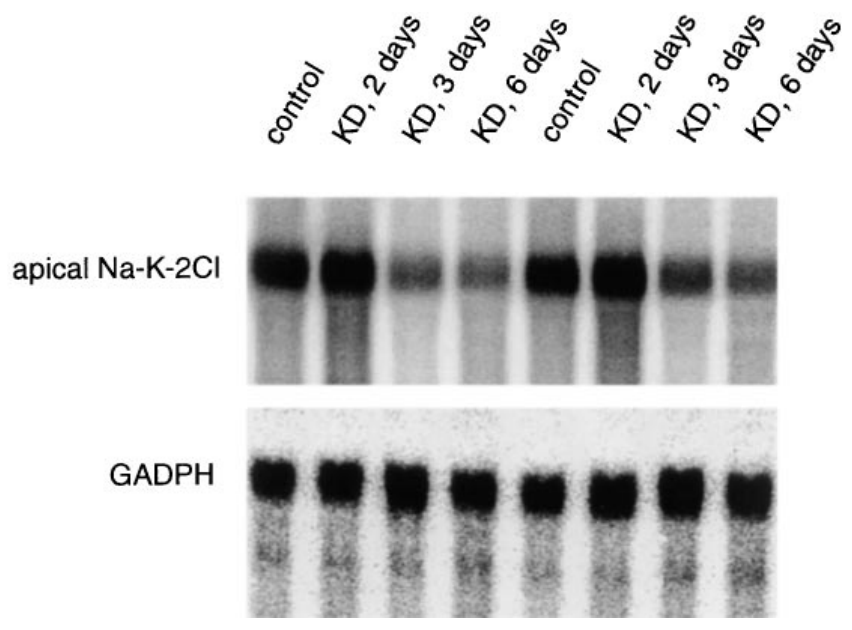

Figure 10. Apical Na-K-2Cl cotransporter Northern hybridization. mRNA expression of the apical Na-K-2Cl cotransporter was measured in the renal outer medulla of rats on KD diet for correlation with urinary chloride excretion studies in Fig. 8.

changes in the abundance or distribution of the chloride-transporter proteins can also affect the activity of the cotransporter independent of gene regulation.

The majority of chloride reabsorption in the distal convoluted tubule is mediated by the thiazide-sensitive apical $\mathrm{Na}-\mathrm{Cl}$ cotransporter (14). Micropuncture studies indicate that KD impairs $\mathrm{Cl}^{-}$reabsorption in the distal tubule (6). The results of these Northern hybridization studies show that $\mathrm{Na}-\mathrm{Cl}$ cotransporter mRNA levels are decreased after as early as $48 \mathrm{~h}$ of KD (Fig. 9). Decreased expression of the $\mathrm{Na}-\mathrm{Cl}$ cotransporter in $\mathrm{KD}$ is consistent with the proposal that decreased $\mathrm{Cl}^{-}$reabsorption in the distal tubule could contribute to increased excretion of $\mathrm{Cl}^{-}$in the urine.

A basolateral Na-K-2 $\mathrm{Cl}$ cotransporter has been suggested to be involved in the regulation of cell volume (15). Basolateral Na-K-2Cl cotransporter mRNA levels did not change during $\mathrm{KD}$ (Fig. 12), indicating that suppression of the $\mathrm{Cl}$ transporters in $\mathrm{KD}$ is limited to luminal $\mathrm{Cl}$ isoforms. In addition to the basolateral Na-K-2Cl cotransporter, a basolateral $\mathrm{K}^{+}-\mathrm{Cl}^{-}$ cotransporter is also expressed in several nephron segments and is thought to be involved in transport of $\mathrm{Cl}^{-}$and $\mathrm{K}^{+}$from cell to the blood. Expression of the $\mathrm{K}^{+}-\mathrm{Cl}^{-}$cotransporter remained unchanged in KD (data not shown).

Fig. 13 is a schematic diagram comparing the renal expression of chloride cotransporters in potassium depletion (bottom) versus the normal condition (top). According to this proposed scheme, suppression of the apical $\mathrm{Na}-\mathrm{K}-2 \mathrm{Cl}$ and $\mathrm{Na}-\mathrm{Cl}$ cotransporters decreases reabsorption of chloride, sodium, and potassium and increases their delivery to distal nephron segments. Sodium is most likely reclaimed via sodium channel whereas potassium is reabsorbed via enhanced colonic $\mathrm{H}^{+}-\mathrm{K}^{+}$ATPase in more distal segments (23). Chloride, however, is excreted in the urine, resulting in hypochloremia and eventually volume depletion. Hypochloremia, which has been consistently observed in hypokalemia, could further contribute to decreased glomerular fibrilation rate and the maintenance of metabolic alkalosis in KD (2).

Decreased expression and activity of the apical Na-K-2Cl cotransporter may play an important role in the renal concen-

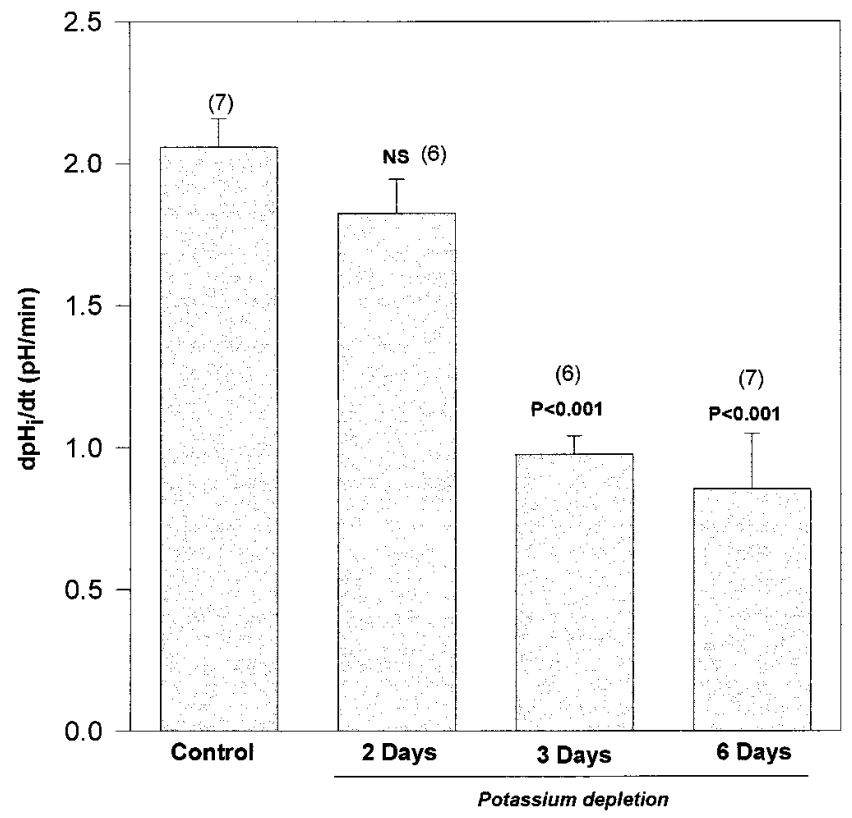

Figure 11. Apical Na-K-2Cl cotransporter activity. The activity of the apical Na-K-2Cl cotransporter was assayed in mTAL tubule suspensions of rats on KD diet for correlation with corresponding Northern hybridization studies in Fig. 10.

trating defect that has been observed in KD in both man (26, 27) and rat $(4,28,29)$. Medullary interstitial osmotic gradients are maintained to a large extent by the reabsorption of sodium and chloride in the mTAL via the apical $\mathrm{Na}-\mathrm{K}-2 \mathrm{Cl}$ cotransporter (11-13). Inhibition of the apical Na-K-2Cl cotransporter (i.e., by furosemide) can reduce the interstitial osmotic gradient in the medulla and impair stimulation by ADH of water reabsorption in medullary collecting duct cells (30). Decreased expression and activity of the renal Na-K-2Cl cotransporter in the medulla of KD animals (Figs. 2-5) would reduce reabsorption of sodium and chloride and could result in the decreased medullary osmotic gradient that has been observed in this condition (4, 26-29). This in turn could blunt the action of $\mathrm{ADH}$; and, in conjunction with the suppression of Aquaporin 2 function (31), result in the urinary concentrating defect that is observed in potassium depletion.

Potassium depletion helps to maintain metabolic alkalosis by increasing the excretion of $\mathrm{NH}_{4}{ }^{+}$(32). Ammonium is synthesized in the mitochondria of proximal tubule cells, transported to the cytosol, and excreted in part via the $\mathrm{Na}^{+} / \mathrm{H}^{+}$exchanger NHE-3 (33). Once in the lumen of the proximal tubule, $\mathrm{NH}_{4}{ }^{+}$is delivered to the mTAL where it is reabsorbed predominantly by the apical $\mathrm{Na}-\mathrm{K}-2 \mathrm{Cl}$ cotransporter $(20,34)$. The reabsorbed $\mathrm{NH}_{4}{ }^{+}$enters the interstitium, is transported to the medullary collecting duct cells, and is then secreted into the collecting duct lumen (34). Potassium depletion is associated with increased ammoniogenesis (32), suggesting increased reabsorption of $\mathrm{NH}_{4}{ }^{+}$in mTAL and increased secretion in the collecting duct. Suppression of the Na-K-2Cl cotransporter by KD suggests that increased reabsorption of $\mathrm{NH}_{4}{ }^{+}$during KD in mTAL (as would be expected to be the case if $\mathrm{NH}_{4}^{+}$excretion is increased) is likely mediated via another transporter, such as the $\mathrm{K}^{+} / \mathrm{NH}_{4}{ }^{+}$antiporter (19). Alter- 


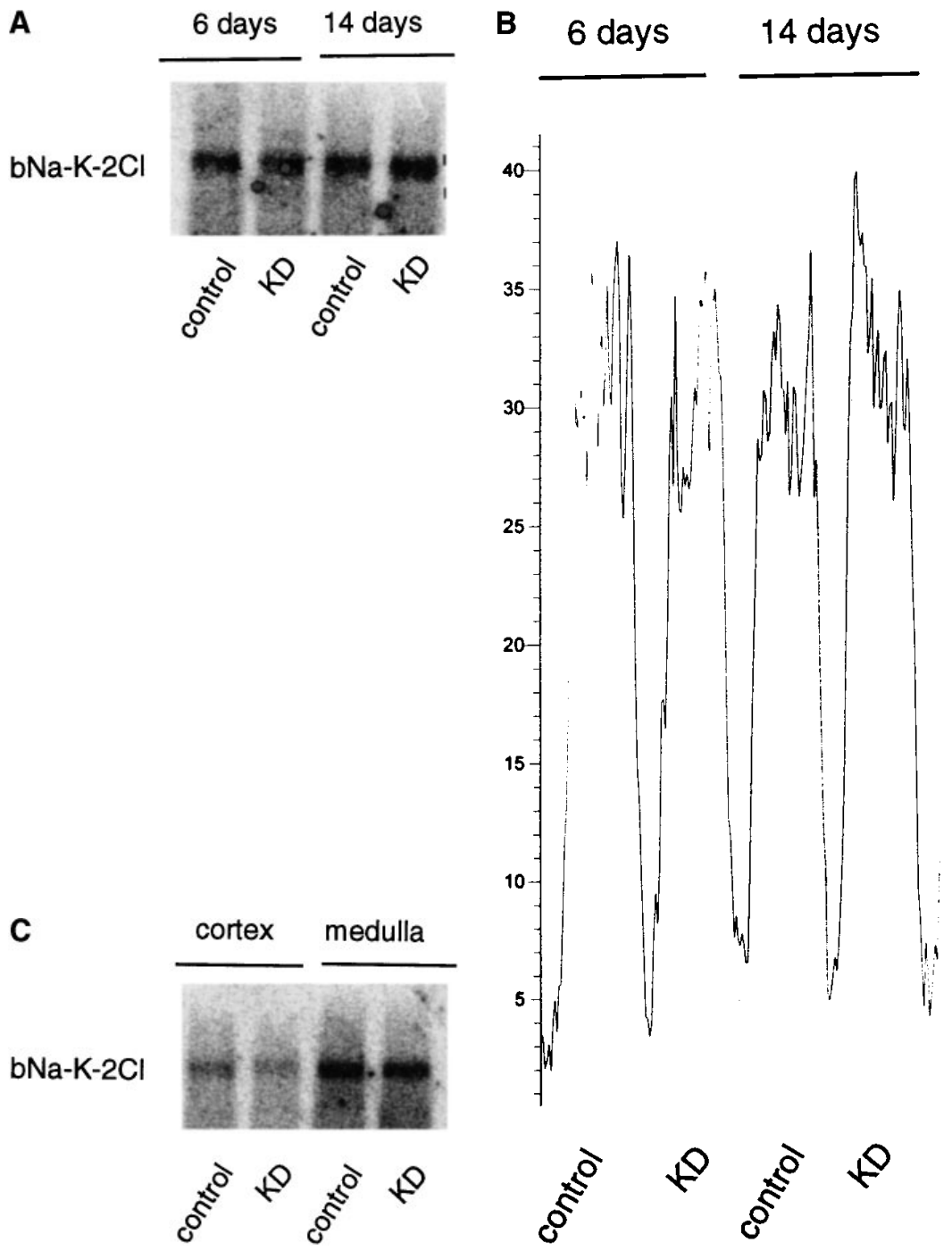

Figure 12. Basolateral Na-K-2Cl cotransporter Northern hybridization. Apical Na-K-2Cl cotransporter Northern hybridization. $(A)$ Representative Northern hybridization showing basolateral $\mathrm{Na}-\mathrm{K}$ $2 \mathrm{Cl}$ cotransporter transcript levels at 6 and $14 \mathrm{~d}$ of $\mathrm{KD}$, respectively. $(B)$ Densitometric scanning of the results shown in $A$. $(C)$ is a representative Northern hybridization showing basolateral $\mathrm{Na}-\mathrm{K}-2 \mathrm{Cl}$ cotransporter mRNA expression in cortex and medulla at $14 \mathrm{~d}$ of potassium depletion. Basolateral $\mathrm{Na}-\mathrm{K}-2 \mathrm{Cl}$ cotransporter transcript size was $\sim 6.5 \mathrm{~kb}$ $30 \mu \mathrm{g}$ RNA were loaded on each lane. Corresponding nitrocellulose membrane-transferred RNA and GAPDH mRNA levels are shown in Fig. 1.

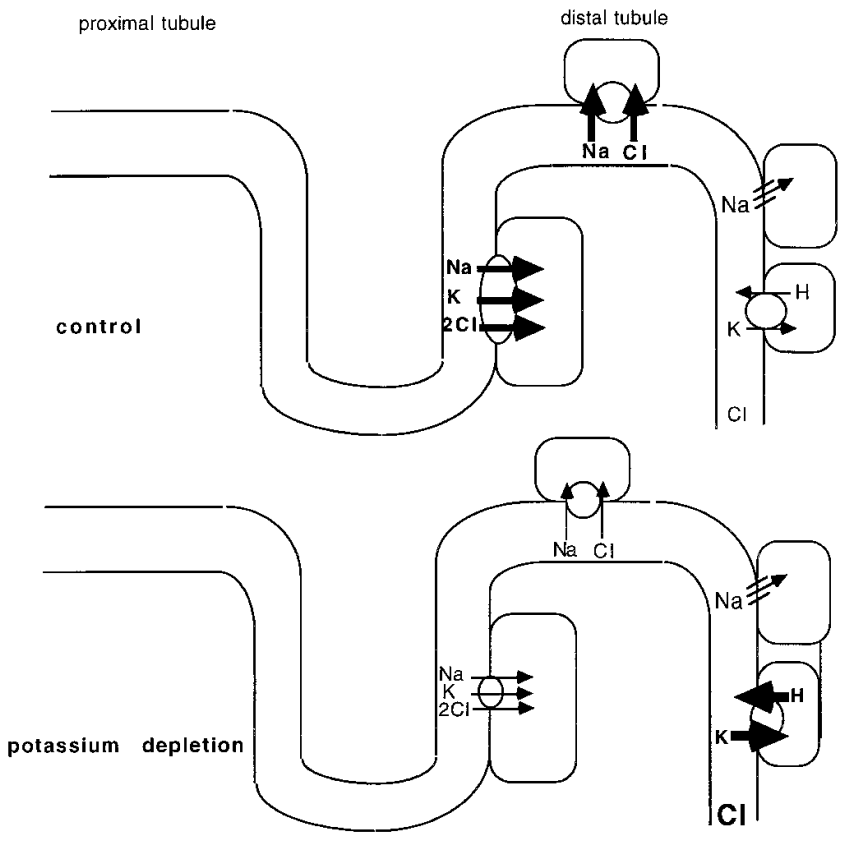

natively, it is possible that while the $\mathrm{Na}-\mathrm{K}-2 \mathrm{Cl}$ cotransporter activity is decreased in $\mathrm{KD}$, it could still carry an increased $\mathrm{NH}_{4}{ }^{+}$load, as the reduced luminal $\mathrm{K}^{+}$concentration could result in decreased competition of $\mathrm{K}^{+}$with $\mathrm{NH}_{4}^{+}$for the $\mathrm{K}^{+}$binding site of the cotransporter (35).

One intriguing aspect of these studies is suppression of the $\mathrm{Na}-\mathrm{Cl}$ cotransporter and increased urinary chloride excretion after as early as $48 \mathrm{~h}$ of $\mathrm{KD}$. The $\mathrm{Na}-\mathrm{K}-2 \mathrm{Cl}$ cotransporter is suppressed at $72 \mathrm{~h}$ of $\mathrm{KD}$. The cellular mechanism mediating the suppression of these two transporters in KD is unknown. The possibility that regulatory elements sensitive to intracellular potassium concentration interact with the promoter region of these two transporters needs careful examination. Alternatively, it is possible that decreased expression of these two transporters is secondary to alterations in regulatory hormones (e.g., KD suppresses aldosterone levels). Adrenalectomized animals, however, did not demonstrate any reduction in $\mathrm{Na}-\mathrm{K}$ -

Figure 13. A schematic diagram demonstrating regulation of apical $\mathrm{Cl}^{-}$transporters in normal (top) and potassium depletion (bottom). 
$2 \mathrm{Cl}$ cotransporter mRNA expression (data not shown). It is worth mentioning that KD animals may have changes in cellular ionic composition (such as increased cell $\mathrm{Na}$ due to decreased Na-K-ATPase activity or increased cell $\mathrm{H}^{+}$concentration secondary to $\mathrm{K}_{\mathrm{i}}-\mathrm{H}_{\mathrm{o}}$ exchange) that could affect $\mathrm{Cl}^{-}$uptake or $\mathrm{Na}-\mathrm{K}-2 \mathrm{Cl}$ cotransport activity independent of gene regulation.

In conclusion, mRNA expression and activity of the apical $\mathrm{Na}-\mathrm{K}-2 \mathrm{Cl}$ cotransporter decreased in potassium depletion. Expression of the $\mathrm{Na}-\mathrm{Cl}$ cotransporter mRNA was also decreased in potassium depletion. Decreased expression of these two major $\mathrm{Cl}^{-}$transporters could lead to decreased reabsorption and increased renal excretion of chloride during potassium depletion. The signal responsible for suppression of these transporters in potassium depletion precedes hypokalemia and is likely activated by intracellular $\left[\mathrm{K}^{+}\right]$depletion.

\section{Acknowledgments}

The authors acknowledge the excellent technical assistance of Holli Shumaker. The critical review of this manuscript by Dr. John Galla and Dr. Charles Burnham is greatly appreciated.

These studies were supported by the National Institute of Health grant DK 46789 and by a grant from Dialysis Clinic Incorporated (M. Soleimani).

\section{References}

1. Garella, S., J.A. Chazan, J.J. Cohen. 1970. Saline-resistant metabolic alkalosis or "chloride wasting nephropathy". Ann. Intern. Med. 73: 31-35.

2. Luke, R.G., and H. Levtin. 1967. Impaired renal conservation of chloride and the acid base changes associated with potassium depletion in the rat. Clin. Sci. (Lond.). 32:511-526.

3. Mannitius, A., H. Levitin, D. Beck, and F.H. Epstein. 1960. On the mechanism of impairment of renal concentrating ability in potassium deficiency. $J$. Clin. Invest. 39:684-692.

4. Buckalew, V.M., M.S. Ramirez, and M. Goldberg. 1967. Free water reabsorption during solute diuresis in normal and potassium-depleted rats. Am. J. Physiol. 212:381-386.

5. Struyvenberg, A., J. DeGraeff, L.D.F. Lameijer. 1965. The role of chloride in hypokalemic alkalosis in the rat. J. Clin. Invest. 44:326-338.

6. Luke, R.G., F.S. Wright, N. Fowler, M. Kashgarian, and G.H. Giebisch. 1978. Effect of potassium depletion on renal tubular chloride transport in the rat. Kidney. Int. 14:414-427.

7. Gamba, G., A. Myanoshita, M. Lombardi, J. Lytton, W.S. Lee, M.A. Hediger, and S.C. Hebert. 1994. Molecular cloning, primary structure, and characterization of two members of the mammalian electroneutral sodium-(potassium)-chloride cotransporter family expressed in kidney. J. Biol. Chem. 269: 17713-17722.

8. Yang, T., Y.G. Huang, I. Singh, J. Schnermann, and J.P. Briggs. 1996. Localisation of bumetanide-sensitive Na-K-Cl cotransporters along the rat nephron. Am. J. Physiol. 271(Renal Fluid Electrolyte Physiol.):F931-F939.

9. Xu, J.C., C. Lytle, T.T. Zhu, J.A. Payne, E. Benz, Jr., and B. Forbush III 1994. Molecular cloning and functional expression of the bumetanide-sensitive Na-K-Cl cotransporter. Proc. Natl. Acad. Sci. USA. 91:2201-2205.

10. Burg, M.B. 1976. Tubular chloride transport and the mode of action of some diuretics. Kidney. Int. 9:189-197.

11. Rocha, A.S., J.P. Kokko. 1973. Sodium chloride and water transport in the medullary thick ascending limb of Henle: evidence for active chloride transport. J. Clin. Invest. 52:612-623.

12. Hebert, S.C., and T.E. Andreoli. 1984. Control of $\mathrm{NaCl}$ transport in the thick ascending limb. Am. J. Physiol. 246(Renal Fluid Electrolyte Physiol.): F745-F756.

13. Ellison, D.H., H. Velasquez, and F.S. Wright. 1987. Thiazide-sensitive chloride transport in early distal tubule. Am. J. Physiol. 253(Renal Fluid Electrolyte Physiol.):F546-F554.

14. Stokes, J.B. 1989. Electroneutral $\mathrm{NaCl}$ transport in the distal tubule. Kidney Int. 36:427-433.

15. Delpire, E., M.I. Rauchman, D.R. Beier, S. Hebert, and S.R. Gullan. 1994 Molecular cloning and chromosomal localization of a putative basolateral Na$\mathrm{K}-2 \mathrm{Cl}$ cotransporter from mouse inner medullary collecting duct (mIMCD-3) cells. J. Biol. Chem. 269:25677-25683.

16. Soleimani, M., J.A. Bergman, M.A. Hosford, and T.D. McKinney. 1990 Potassium depletion increases $\mathrm{Na}^{+} / \mathrm{H}^{+}$exchange and $\mathrm{Na}^{+}: \mathrm{HCO}_{3}{ }^{=}: \mathrm{HCO}_{3}{ }^{-}$ cotransport in rat renal cortex. J. Clin. Invest. 86:1076-1083.

17. Chomczynski, P., and N. Sacchi. 1987. Single-step method of RNA isolation by acid guanidinium thiocynate-phenol-chloroform extraction. Anal. Biochem. 162:156-159.

18. Church, G.M., and W. Gilbert. 1984. Genomic sequencing. Proc. Natl. Acad. Sci. USA. 81:1991-1995.

19. Amlal, H., M. Paillard, and M. Bichara. 1994. $\mathrm{NH}_{4}{ }^{+}$transport pathways in cells of medullary thick ascending limb of rat kidney. J. Biol. Chem. 269: 21962-21971.

20. Amlal, H., M. Paillard, and M. Bichara. 1994. $\mathrm{Cl}^{-}$-dependent $\mathrm{NH}_{4}{ }^{+}$ transport mechanisms in medullary thick ascending limb cells. Am. J. Physiol. 267(Cell Physiol.):C1607-C1615.

21. Amlal, H., C. Legoff, C. Vernimmen, M. Paillard, and M. Bichara. 1996. $\mathrm{Na}^{+}-\mathrm{K}^{+}\left(\mathrm{NH}_{4}^{+}\right)-2 \mathrm{Cl}^{-}$cotransport in medullary thick ascending limb: control by PKA, PKC, and 20-HETE. Am. J. Physiol. 271(Cell Physiol.):C455-C463.

22. Kinne, R., E. Kinne-Saffran, H. Schutz, and B. Scholermann. 1986. Ammonium transport in medullary thick ascending limb of rabbit kidney: involvement of the $\mathrm{Na}^{+}, \mathrm{K}^{+}, \mathrm{Cl}^{-}$-cotransporter. J. Membr. Biol. 94:279-284.

23. Wang, Z., B. Nancy, H. Shumaker, and M. Soleimani. 1997. Potassium depletion and acid-base transporters in rat kidney: differential effect of hypophysectomy. Am. J. Physiol. 272:F736-F743.

24. Luke, R.G., B. Beverly, and J.H. Galla. 1985. Effect of potassium depletion on tubular chloride transport in the loop of Henle in the rat. Am. J. Physiol. 248 (Renal Fluid Electrolyte Physiol.):F682-F687.

25. Hass, M., and T.J. McManus. 1983. Bumetanide inhibits (Na-K-2Cl) cotransport at a chloride site. Am. J. Physiol. 245:C235-C240.

26. Relman, A.S., and W.B. Schwartz. 1956. The nephropathy of potassium depletion: a clinical and pathological entity. N. Engl. J. Med. 255:195-203.

27. Relman, A.S., and W.B. Schwartz. 1958. The kidney in potassium depletion. Am. J. Med. 24:764-773.

28. Bank, N., and H.S. Aynedjian. 1964. A micropuncture study of the renal concentrating defect of potassium depletion. Am. J. Physiol. 206:1347-1354.

29. Holiday, M.A., R.W. Winters, L.G. Welt, M. McDowell, and J. Oliver. 1959. The renal lesion of electrolyte imbalance. II. The combined effect on renal architecture of phosphate loading and potassium depletion. J. Exp. Med. 110:161-168.

30. Hook, J.B., H.E. Williamson. 1965. Effect of furosemide on renal medullary sodium gradient. Proc. Soc. Exp. Biol. Med. 118:372-374.

31. Marples, D., J. Frokiaer, J. Dorup, M.A. Knepper, and S. Nielsen. 1996 Hypokalemia-induced downregulation of aquporin-2 water channel expression in rat kidney medulla and cortex. J. Clin. Invest. 97:1960-1968.

32. Tannen, R.L. 1977. Relationship of renal ammonia production and potassium homeostasis. Kidney Int. 11:453-456.

33. Kinsella, J.L., and P.S. Aronson. 1981. Interaction of $\mathrm{NH}_{4}{ }^{+}$and $\mathrm{Li}^{+}$with the renal microvillus membrane $\mathrm{Na}^{+} / \mathrm{H}^{+}$exchanger. Am. J. Physiol. 241 (Cell Physiol.):C220-C226.

34. Good, D.W., and M. Knepper. 1985. Ammonia transport in the mammalian kidney. Am. J. Physiol. 248:F459-F471.

35. Good, D.W. 1988. Active absorption of $\mathrm{NH}_{4}{ }^{+}$by rat medullary thick ascending limb: inhibition by potassium. Am. J. Physiol. 255:F78-F87. 